\title{
Sauna aikakoneena - löylyjen luoma matka muistoihin ja maisemaan
}

\author{
Lectio praecursoria Turun yliopistossa 8.6.2018
}

\section{Laura Seesmeri}

\begin{abstract}
Kun löylyä lyötiin, kuului ulos asti kihaus ja hirsien raoista tussahti höyry viilenevään iltailmaan ja vastan mätke kuului veden kantamana kauas järven selälle. Järveltä nähtynä kuva oli kuin taideteos, jossa mahtava luonto ja ihmiskäden jälki sopivat hyvin yhteen, melkeinpä paransivat toinen toistaan. (SKS. SAUNA, 2493.)
\end{abstract}

Näin kuvailee saunaa ja saunomista yksi tutkimusaineistoni vastaaja, vuonna 1919 syntynyt mies. Tässä kuvauksessa on meille kaikille jotain hyvin tuttua. Jos emme ole itse nähneet, kuulleet ja tunteneet tuohon näkyyn liittyvää kokemusta saunasta rantamaisemassa, voimme ainakin kuvitella sen.

Suomessa on tilastokeskuksen mukaan asuntojen rakennuskannassa yli kaksi miljoonaa saunaa ja viiden ja puolen miljoonan suuruisesta väestöstä lienee lähes jokainen joskus saunonut. Saunoja on kerrostalojen huoneistoissa, taloyhtiöiden kellareissa tai vinteillä, rivitaloissa, omakotitaloissa, tonttien pihoilla, kesämökeillä. On uimahallien saunoja, maauimaloita, kuntokeskusten saunoja, hotellisaunoja, kylpylöitä. Saunoja on laivoissa ja liikkuvia saunoja pyörien päällä. Vaikka saunat ovat olemuksiltaan hyvinkin erilaisia, on saunomiskokemuksissa aina kuitenkin jotain samankaltaista. Kuuma on aina kuumaa, ovi kiinni, saunoja alasti ja mitä todennäköisimmin lauteilla. Saunomisen yhteyttä menneisyyteen luo myös saunomisen luonne Suomessa yli sukupolvien ylittyvänä usein perheen sisäisenä tapana. Saunomista ei täydy opetella, siihen kasvetaan ja se liittyy nykypäivänäkin useaan asiaan ihmiselämässä.

\section{Osa elämää, osa kulttuuriperintöä}

Ei minua opetettu saunomaan. Minä synnyin saunaan, toteaa yksi aineistoni vastaajista, vuonna 1925 syntynyt nainen (SKS. SAUNA, 3604). Muutama päivä sitten Opetus- ja kulttuuriministeriö julkaisi tiedotteen saunomisen esittämisestä Suomen ensimmäiseksi ehdotukseksi Unescon Ihmiskunnan aineettoman kulttuuriperinnön luetteloon. Näin saunominen halutaan nostaa aineettoman kulttuuriperinnön suomalaiseksi esimerkiksi.

Suomi allekirjoitti viisi vuotta sitten Unescon yleissopimuksen aineettoman kulttuuriperinnön suojelemisesta. Suojelun lisäksi sopimuksen puitteissa tehdään kulttuuriperinteitä 
näkyviksi. Sopimukseen kuuluu myös aineettoman kulttuuriperinnön luetteloiminen kansallisesti ja kansainvälisesti. Suomessa aineetonta kulttuuriperintöä kerätään Elävän perinnön wikiluetteloon, josta viime keväänä oli mahdollisuus hakea kohteita elävän perinnön kansalliseen luetteloon. Marraskuussa opetus- ja kulttuuriministeriö nimesi ensimmäiset 52 kohdetta tässä luettelossa. Yksi näistä on saunominen. Listalta löytyy myös mm. kaustislainen viulunsoittoperinne, jota ehdotetaan saunomisen jälkeen seuraavaksi esitykseksi kansainväliseen luetteloon. Muita ilmiöitä kansallisella listalla ovat esimerkiksi jokamiehenoikeudet, laihialainen nuukuus, runolaulu ja pesäpallo.

Unescon kansainvälisellä aineettoman kulttuuriperinnön listalla on jo yksi esimerkki saunasta; Viron Võrumaan savusaunaperinne hyväksyttiin listalle vuonna 2014. Tähän perinteeseen liitetään perheen sisäinen lauantaisauna, vihdan tekemisen taito, saunan rakentaminen, kansanparannus ja lihan savustaminen saunassa. Suomen esityksessä luetteloinnista saunomista ei rajata tiettyyn saunomismuotoon. Päinvastoin saunomista korostetaan niin luonnollisena osana monen suomalaisen elämää, että saunoessa ei edes tiedosteta aineettoman kulttuuriperinnön elinvoimaisena pitämistä ja siirtämistä eteenpäin.

Saunominen onkin melkoinen runsaudensarvi siihen liittyvine tapoineen, uskomuksineen, vanhoine taloustöineen, kansanparannukseen liittyvine toimineen ja moninaisine rooleineen elämän syklissä syntymästä erilaisten siirtymäriittien kautta kuolemaan. Kaiken tämän ohella nämä seikat tulevat esille myös kansallisessa aineettoman perinnön wikiluettelossa saunasta. Saunominen on arkinen tapahtuma ja voimakas kehollinen kokemus. Sillä tuntuu kuitenkin jo tämän luettelossa esitetyn tekstinkin perusteella olevan voimakas suhde menneisyyteen, tapoihin ja merkityksiin. Ne elävät saunomisen taustalla tiedostettuna saunakulttuurina, vaikka kyse olisi pelkästä arkisesta nykyaikaisesta saunomisesta: esimerkiksi kotona huoneistosaunan lämmittämisestä työpäivän päätteeksi.

\section{Kohti kokemuksen tutkimista}

Miksi tutkia saunomista? Kaikkihan tietävät, mitä saunominen on ja miltä se tuntuu. Suomessa on tehty hyvin vähän humanistista saunaan liittyvää tutkimusta ja saunomiskokemusta kulttuurillisesta näkökulmasta ei ole tutkittu juuri lainkaan. Sauna on niin ilmeinen osa arkea, että se on ollut helppo unohtaa tutkimuksen polttopisteestä. Saunomiskokemus antaa kuitenkin tutkimuskohteena oivan esimerkin kehollisen ja aistimellisen kokemuksen tutkimiselle ja sille, miten menneisyys, on se sitten omia muistoja tai kollektiivisesti jaettuja kokemuksia, ohjaavat tätä kokemusta tai ovat siinä läsnä.

Kiinnostus saunaan tutkimuskohteena liittyy itselläni paikan kokemukselliseen tutkimiseen, siihen, miten menneisyyttä hyödynnetään mainonnassa sekä aistimellisuuden ja kehollisuuden välittymiseen kirjallisessa muistitiedollisessa arkistoaineistossa. Näistä lähtökohdista olen koonnut tutkimukseni aineiston, joka koostuu kahdesta Suomalaisen Kirjallisuuden Seuran kansanrunousarkiston järjestämästä sauna-aiheisesta muistitietokeruusta ja kiuasmainoksista.

Keruista ensimmäinen on järjestetty vuonna 1992. Se kerrytti aineistoa yli 3700 liuskan verran liki 480:Ita vastaajalta. Toinen keruu on vuodelta 2010-2011. Tähän keruuseen vastasi liki 60 ihmistä ja vastauksia kertyi reilu 300 liuskaa. 
Keruissa perinnettä käsitellään hieman eri tavoin. Vanhemmassa keruussa on vielä esillä perinnelajit ja saunaa arvotetaan osana yhteistä kansallista omaisuutta. Uudemmassa keruussa puhutellaan vastaajaa ja kerätään selkeämmin hänen omia kokemuksiaan. Vaikka keruut ovat luonteeltaan hieman toisistaan poikkeavat ja niillä on omat teemansa - ensimmäinen keruu painottui saunaan terveyden lähteenä ja toinen miesten ja naisten saunomisen eroihin - on niiden kokemuksellinen kerronta hyvin samankaltaista. Saunasta kerrotaan omaelämäkerran muodossa muistellen elämän varren kaikkia saunoja ja kokemukseen painottuva kerronta on hyvin poeettissävyistä. Kerrottu saunakokemus on moniaistinen ja moneen aikatasoon haarautuva.

Molemmista käyttämistäni muistitiedollisista aineistoista välittyy samanlainen kuva saunomiskokemuksista. Keruiden kertojat jopa kurittomasti sivuuttavat keruiden aiheen ja kertovat itse saunomisesta. Esimerkiksi vuoden 1992 keruuseen vastannut mies toteaa:

Onko saunominen terveellistä? Sitä ei kertomusten tapahtumien aikoihin (luultavasti 50-lukua) kukaan kysynytkään. Koko kysymys on karkea. Onko ilo, onni, hymy terveellistä? Niiden takia ihmiselossa otetaan suurempiakin riskejä kuin saunominen. (SKS. SAUNA, 2346.)

Sauna on tärkeä tunteiden kiinnittymisen paikka. Kokemukseen liittyy muistoja ja tunteita, joita voidaan saunoa uudestaan esille. Kiuasmainonta hyödyntää saunaperinnettä, sen kokemuksellisuutta ja siihen liittyviä tunteita mainostaessaan kiukaita saunoville suomalaisille. Mainokset kulttuurintutkimuksen lähteinä ovat peili omaan aikaansa. Mainonta on viestintää, joka on syntynyt kuluttamisen ja teollisen massatuotannon myötä. Kiukaita on alettu teollisesti valmistamaan Suomessa jo 1930-luvulla ja aktiivisesti niitä on mainostettu usean valmistajan taholta viimeistään 1950-luvulta lähtien. Näin kiuasmainonta kattaakin lähes koko suomalaisen mainonnan historian kaaren, ja niitä tarkastelemalla voidaan myös havaita yleisiä mainonnan linjojen muutoksia. Tarkastelemalla saunomiskokemusta saunojien kerronnan välittämänä ja kaupiteltua saunomiskokemusta mainosten kautta olen pystynyt piirtämään kulttuurillisen kokonaiskuvan saunomisesta.

Metodini ovat perustuneet lähilukemiseen. Tutkin kokemusta eri tasoisten representaatioiden kautta. Kokemuskertomukset saunasta ovat lähempänä itse kokemusta kuin mainoksissa argumentoitu ja kaupiteltu kokemuksellisuus. Liikun strukturalistisen ja subjektiivisen välillä. Koen, että kaikessa etnografiassa on kyse tästä. Tutkin saunan etnografiaa kokemuksen kautta, jossa on sekä aikaan että paikkaan sidottu ulottuvuutensa.

\section{Aikamatka lauteilla - osana maisemaa}

Istun lauteilla. Sähkön lämmittämien kivien sihahtaessa toisenlaisen, pehmeämmän sihahduksen vuosien takaa. Istun lauteilla äitini kanssa oman viisivuotiaani kokoisena ja oloisena. Ulkoa kuuluu tuulen vongahtelua ja napsahduksia. Saunan seinustalla seisova koivu pyyhkäisee alaoksillaan pärekattoa. Lämpimän lempeä höyry kietoo minut ja työn uuvuttaman äitini omaan rauhoittavaan maailmaansa. Meitä valaisee vain matalalle kaksiruutuisen ikkunan taakse naulaan ripustetun lyhdyn tuulessa lepattava liekki. Tuon valoympyrän ulkopuolella on läpitunkematon pimeys

$[\ldots]$

Havahdun humahdukseen, joka jatkuu tasaisen vaimeana. IImastointilaite huolehtii saunani ilmanvaihdosta. Seinät ovat hohtavan puhdasta puuta. Löylyveteen olen pudottanut viisi pisaraa pienestä pullosta, jonka kyljessä on koivunlehden kuva. Mustaseinäinen sauna on olemassa enää kylpijöittensä muistoissa. 
Tällaisen aikamatkan kokee aineistoni vuonna 1953 syntynyt nainen. Saunoessa kuultu sihahdus yhdistyy muistoihin ja kuulostaa erilaiselta, pehmeämmältä. Sähkösaunassa aistitut tuoksut ja äänet yhdistyvät muistojen saunaan. Saunamaisema alkaa eläää saunojan muistoissa. Tässä hetkessä ja nyt ovat läsnä kiukaan kivet ja höyryksi sihahtava vesi, mutta ne kietoutuvat kokemuksessa lapsuuden saunan pärekattoa pyyhkäisevään koivuun, tuulen vongahteluun ja myrskylyhdyn tuulessa lepattavaan liekkiin.

Maisema ja luontosuhde nousevat olennaiseksi osaksi saunakokemusta ja tämän kokemuksen moninaisia ajallisia tasoja. Ymmärrän saunan paikaksi, joka on osa maisemaa ja jolla on maisemansa. Maisema on tässä paikkoja kokoava käsite, yhteenkuuluvien paikkojen kimppu ja panoraama paikoista, joita intensiivisesti eletään. Konkreettisen meitä ympäröivän ja aistein koettavan ympäristön lisäksi maisema on mielenmaisemaa, jossa subjektiiviset ja intersubjektiiviset käsitykset paikasta kohtaavat. Kokijoina saunojat ovat risteyksessä, jossa maa kohtaa mielen, jossa mieli kohtaa kehon, menneisyys kohtaa nykyisyyden, aistit kohtaavat muistot ja oleminen kohtaa tekemisen. Saunamaiseman menneisyys muodostuu saunomisen ja saunatilan stimuloimista muistoista ja itse saunatilan viittauksellisesta luonteesta pois nykyajasta. Menneisyys on kokemuksessa, ei aikaan vaan paikkaan sidottuna.

Maiseman elementit tulevat osaksi paikkaa; ne aistitaan ja koetaan ja esitetään saunan yhteydessä ja saunan merkitys sisältää sen maisemallisuuden. Se on kulttuurinen konstruktio luonnosta ja sen ilmiöistä, muun muassa vedestä, lämmöstä, puusta ja kivestä. Kulttuurillisesti sitä ei voida ymmärtää sen luontoa ja maisemaa sivuuttamatta. Saunan maisema välittyy kehollisiin muistoihin kerrostuneena aistimellisena ja elettynä maisemana ja paikkana. Kehollisuuden ja kokonaisvaltaisen aistimellisuuden kautta se on emotionaalisten muistojen merkitsemää kokemista.

Maisemalliset muistot ja merkitykset ovat olennainen osa saunomiskokemusta. Maisemaa tuodaan myös esille kiukaita mainostettaessa. Jopa itse mainostettavat kiukaat saattavat esittää maisemaa, jota myös merkityksellistetään osaksi tunteita. Maisema määritellään rentouttavaksi tai räiskyväksi. Maisemaa tuodaan saunamainoksissa paljon esille sen yksityiskohtaisten elementtien käyttämisellä kuvituksessa.

Myytävien kiukaiden lisäksi kuvataan tulen liekkiä, kiveä, puupinoa, koivun oksia. Maisemaa tuodaan esille myös mainosten sanallisessa argumentoinnissa ja tällöin viitataan samalla myös voimakkaasti menneisyyteen. Esimerkiksi kiveä kuvaillaan "kaiken aluksi", "ajan peiliksi" ja "ikuisuuden symboliksi". Samaten tulta argumentoidaan mahtipontisesti sanomalla sen olevan "ihmiskunnan merkittävin keksintö, jonka äärellä yhä edelleen saavutetaan rauha ja yhteys alkukantaiseen itseemme".

\section{Menneisyyden läsnäolo ja esteettisyys}

Menneisyyden läsnäolo on maiseman ohella olennainen osa saunomiskokemusta. Menneisyys saunakokemuksissa on omia muistoja ja yhteistä perinnettä. Se on myös voimakkaasti sidoksissa kulttuuriperintöön ja sen esteettisyyteen. Kokemuskerronnasta välittyvät menneisyyskokemukset ovat rinnastettavissa esteettisiin kokemuksiin. Ne välittävät pysähtyneisyyttä ja kokemuksen kokonaisvaltaisuutta, vaikeasti määriteltävissä olevaa tunteikkuutta ja hetkellistä läheisyyden tunnetta toiseuteen, jonka ne konstruoivat kokemuksessa osaksi henkilökohtaista elämysmaailmaa. Esteettinen kokemus on jotain enemmän kuin normaalia 
arjen virtaa. Samalla tavalla kuin kokemus menneisyyden läsnäolosta nykyhetkessä. Kulttuuriperinnöksi mielletyn saunan kokemuksellisuutta on mielekästä tulkita esteettisen kokemuksen kautta myös sen takia, että molempiin, niin kulttuuriperintöön kuin esteettisyyteenkin liittyy kollektiivisuutta. Kulttuuriperintö on yhteisesti jaettua arvomaailmaa ja menneisyyden jäljistä prosessoitu kokonaisuus. Sauna kulttuuriperinnöllisenä paikkana on kollektiivisesti arvotettu. Samaten esteettiset kokemukset ovat kulttuurillisia, vaikka niihin liittyy myös omakohtaisuuden leima, joka tekee niistä merkityksellisiä. Esteettinen kokemus yhdistää omakohtaista ja kulttuurillista. Siinä elämysmaailma ja eletty maailma kohtaavat ja muokkaavat kokemuksesta muisteltavan arvoisen.

Saunojat myös itse arvottavat ihania ja onnistuneita saunakokemuksiaan esteettisesti. Ja saunomiskokemukseen liittyy ympäröivän maiseman havainnoiminen ja siitä kertominen monisanaisesti sen kauneutta painottaen ja omaa kehollista kokemusta korostaen:

\begin{abstract}
"Jäähyttelyn" tai vilvoittelun aikana pihamaalla kauniina kesäiltana tuli sävähdyttävä pysähtymisen aika, jolloin aisti kirkkaana sireenien tuoksun, kuuli pääskysen liverryksen vinttikaivon nokasta, kaukaiset karjankellojen kumut vaaroilta, ruisrääkän iltamyöhäiset kutsut poikasilleen. Saunan puhdistautumisrituaali oli julistanut pyhän alkaneeksi. Sanoihan Jumalakin seitsemäntenä aamuna luomistyöstään: "Katso kaikki on sangen kaunista ja hyvää." Vastakohtaisuuksien kautta pimeästä savusaunasta kirkkaaseen pohjolan kesäyöhön tulleena saunoja voi sanoa samoin. Kireänä pakkas-iltana saunasta alasti juosten taas tuvan lämpö oli kuin alkutilaan palaamista, kohtu joka otti vastaan puhtaan lapsen ja tuuditti syvään turvalliseen uneen saunan jälkeen.
\end{abstract}

Näin kertoo aineistoni vuonna 1944 syntynyt nainen. Saunominen kehollisena kokemuksena on moniaistinen ja kokonaisvaltainen kokemus, jossa oma keho asettuu suhteessa aikaan ja paikkaan.

Saunominen toimii suomalaisille aikakoneena, joka sitoo kokijat muistoihin ja maisemaan. Moniaistinen saunakokemus virittää saunojan kokemaan niin kuin ennenkin koettiin.

Myös kiuasteollisuus hyödyntää tätä menneisyyden läsnäoloa saunassa ja se argumentoinnissaan loihtiikin poissa olevaa mukaan kokemuksellisuuteen tarjoilemalla esimerkiksi savusaunamaisia löylyjä, jotka voi tavoittaa helposti napin painalluksella pienen sähkökiukaan kyljestä.

Seesmeri, Laura. 2018. Sauno itsellesi menneisyys: Kehollisuus osana muisteltua ja esitettyä kokemusta. Kultaneito XVIII. Joensuu: Suomen Kansantietouden Tutkijain Seura.

\title{
Lähteet
}

Suomalainen sauna terveydenlähteenä. Suomalaisen Kirjallisuuden Seuran perinteenkeruukilpailu vuodelta 1992.

Filosofian tohtori Laura Seesmeri työskentelee projektitutkijana Turun yliopistossa maisemantutkimuksen oppiaineessa. 